ISSN 0258-7122

Bangladesh J. Agril. Res. 34(4) : 693-703, December 2009

\title{
HAPLOID PLANTLET REGENERATION THROUGH ANTHER CULTURE IN OILSEED Brassica species
}

\author{
M. A. ALAM ${ }^{1}$, M. A. HAQUE ${ }^{2}$, M. R. HOSSAIN ${ }^{3}$ \\ S.C. SARKER ${ }^{4}$ AND R. AFROZ ${ }^{5}$
}

\begin{abstract}
Anther of five varieties of Brassica species, namely BARI Shariaha-7, Tori-7, Agrani, Daulat and Safal were cultured in vitro to observe their regeneration potentiality. Different concentrations and combinations of growth regulators were supplemented in MS medium. The range of callus induction was 12.50$87.50 \%$. Maximum callus induction (75.00\%) was observed on MS $+4 \mathrm{mg} / \mathrm{L} \mathrm{2}$, $4-\mathrm{D}+1.0 \mathrm{mg} / \mathrm{L}$ BAP. Among the genotypes, BARI Sharisha-7 showed the highest percentage of callus induction (60.42\%). Among the treatments, highest percentage of shoot regeneration (75.00\%) was observed on MS + $4 \mathrm{mg} / \mathrm{L} \mathrm{BAP}$ $+1.0 \mathrm{mg} / \mathrm{L}$ NAA. BARI Sharisha-7 also showed the highest rate of plant regeneration (66.67\%). Root induction was highest (75\%) on half strength MS medium supplemented with $1.0 \mathrm{mg} / \mathrm{L}$ IBA and $0.5 \mathrm{mg} / \mathrm{L} \mathrm{NAA}$. The plantlets with sufficient roots thus obtained were transferred successfully to plastic pots and subsequently to the field. BARI Sharisha-7 and Tori-7 survived easily in the pots as well as in the field but Safal was very poor in survivability both in the pots and in the field.
\end{abstract}

Key Words: Brassica, haploid, anther culture, in vitro regeneration.

\section{Introduction}

Bangladesh is principally an agricultural country and produces good number of oilseed crops like mustard, sesame, groundnut, linseed, niger, safflower, sunflower, soybean, castor, etc. The first three of these are considered as the major oil crops. The oleiferous Brassica (rapeseed and mustard) which is commonly termed as mustard plays an important role in vegetable oil production of the world. It is the third most important edible oil source in the world after soybean and palm (FAO, 2003; Piazza and Foslia, 2001; Walker and Booth, 2001). This crop supplies about $13.2 \%$ of the world's edible oil (Downey and Robbelen, 1989).

Recently anther cultures have attracted considerable attention as supplementary tools for the rapid production of haploid and inbred lines and for obtaining hybrid cultivars (Jain et al., 1996; Wenzel et al., 1977a; Keller and Armstrong, 1978). This technique is used to obtain haploid plants (Kasha et al.,

${ }^{1,2 \& 3}$ Department of Genetics and Plant Breeding, Bangladesh Agricultural University, Mymensingh 2202, ${ }^{4}$ Department of Agroforestry, Bangladesh Agricultural University, Mymensingh 2202, ${ }^{5}$ Scientific Officer, Bangladesh Agricultural Research Institute, Joydebpur, Gazipur 1701, Bangladesh. 
1990) and thereby homozygous diploids of economically important varieties or parental lines with additive genetic divergence. The main advantage of using double haploids is the rapid homozygosity of the descendants, results a time saving procedures for the development of new varieties. In oilseed rape, the doubled haploid method can reduce the time by about 2-4 years from 8-10 years required to develop a new cultivar using traditional breeding procedures. The doubled haploid method opens also a unique way for the fixation of hybrid performance in homozygous lines, which would avoid all the problems associated with the production of hybrid seeds. Selected doubled haploids can be used as intermediate parents for $\mathrm{F}_{1}$ hybrids. Doubled haploids are now being used for genome mapping for many genes and/or quantitative trait loci (QTL) in barley (Zivy et al., 1992), oilseed rape and rice (Huang et al., 1994). Haploid embryos or doubled haploid plants can also be used in mutation, genetic engineering, biochemical and physiological studies (Razdan, 1993).

Therefore, to harvest the multifarious merits of anther culture, the present research work was planned and carried out. Main objectives were establishment of a suitable and reproducible protocol for in vitro regeneration of haploid Brassica plantlets through anther culture, optimization of the suitable combination and concentration of hormones on selected media for regeneration of Brassica genotypes, and finally observation of the genotypic variation for callus induction and plantlet regeneration.

\section{Materials and Method}

The experiment was carried out during the period from August 2006 to May 2007 at the Tissue Culture Laboratory and the Biotechnology and Genetic Engineering (BGE) Laboratory of the Department of Genetics and Plant Breeding, Bangladesh Agricultural University, Mymensingh. The seed materials of five varieties of indigenous Brassica species (BARI Shariaha-7, Tori-7, Agrani, Daulat and Safal) were collected from Bangladesh Agricultural Research Institute (BARI), Joydebpur, Gazipur and Bangladesh Institute of Nuclear Agriculture (B1NA), Bangladesh Agricultural University Campus, Mymensingh. Different media compositions were used to investigate the regeneration potentiality.

\section{Media used for anther culture}

MS medium supplemented with 1.0, 2.0 and $4.0 \mathrm{mg} / \mathrm{L}$ 2,4-D along with the constant addition of $1.0 \mathrm{mg} / \mathrm{L}$ BAP were used for callus induction. Likewise, MS medium supplemented with 2.0, 3.0 and $4.0 \mathrm{mg} / \mathrm{L}$ BAP along with the constant addition of $1.0 \mathrm{mg} / \mathrm{L}$ NAA were used for shoot initiation, while half strength MS (Murashige and Skoog, 1962) medium with supplementation of 1.0, 2.0 and $3.0 \mathrm{mg} / \mathrm{L}$ IBA with $0.5 \mathrm{mg} / \mathrm{L}$ NAA in each treatment were used for root initiation. 


\section{Culture method}

Before culture, surface sterilization of flower buds was carried out in the Laminar Air Flow Cabinet. They were rinsed in $0.1 \% \mathrm{HgCI}_{2}$ for one minute, and then thoroughly washed with sterilized distilled water for three times. Then the following culture methods were employed in the present study:

\section{i) Explant culture}

\section{a) Collection of flower buds}

Flower buds of all varieties were collected at the late uninucleate stage in the morning before 10 a.m. Flowers of the Brassica varieties whose bud condition were used as explant (anther and filament) source are presented in plate $1 \& 2$. The developmental stages of the microspores were determined by studying microscopic slides prepared according to the acetocarmine squash method.

\section{b) Cold treatment of flower buds}

Collected flower buds were wrapped in aluminum foil and kept in a refrigerator at $5^{\circ} \mathrm{C}$ for 24 hours.

\section{c) Anther culture}

Anthers were aseptically removed from flower buds using fine tweezers and inoculated into $8 \mathrm{~cm}$ petridishes each containing $10 \mathrm{ml}$ MS medium with different hormone concentrations viz., $\mathrm{T}_{1}$-MS medium containing $\mathrm{l} \mathrm{mg} / \mathrm{L} 2,4-\mathrm{D}+1.0$ $\mathrm{mg} / \mathrm{L}$ BAP, $\mathrm{T}_{2}$-MS medium containing $2 \mathrm{mg} / \mathrm{L} \mathrm{2,4-D}+1.0 \mathrm{mg} / \mathrm{L} \mathrm{BAP}$ and $\mathrm{T}_{3^{-}}$ MS medium containing $4 \mathrm{mg} / \mathrm{L}$ 2,4-D $+1.0 \mathrm{mg} / \mathrm{L}$ BAP with four replications. Cultures were maintained in an incubator at $25^{\circ} \pm 1^{\circ} \mathrm{C}$ temperature in complete dark condition for callus induction and checked to record the response.

\section{ii) Sub-culture or transfer of the callus}

\section{a. Sub-culture or transfer of the callus for shoot regeneration}

Six to seven weeks after inoculation of anthers, the regenerated calli attained convenient size. Then they were removed aseptically from the existing medium to a sterilized culture vessel inside the laminar Air Flow Cabinet. The calli were cut into few pieces and again placed them into the small vials with shoot regeneration media. Sub-culture was done on the MS media containing different concentrations of BAP and NAA. The vials were incubated at $25 \pm 1^{\circ} \mathrm{C}$ with 16 hours photoperiod.

\section{b. Sub-culture or transfer of the regenerated shoot for root induction}

The sub-cultured calli contained to proliferate and differentiate into shoots when these shoots grew $2-3 \mathrm{~cm}$ in length. They were rescued aseptically from the cultured vials and were separated from each other and again cultured on vials 
with freshly prepared root induction medium to induce root. The vials containing plantlet were incubated under continuous light. Day to day observation was carried out to note the response of the growing plantlets.

\section{Preparation of the pots and transplantation}

For the preparation of pots garden soil, sand and cowdung in the ratio of 1:2:1 were mixed properly and autoclaved for one hour in $121^{\circ} \mathrm{C}$ at $1.6 \mathrm{~kg} / \mathrm{cm}^{2}$. Then the soil mixtures was allowed to cool in normal temperature and poured into 10 $\mathrm{cm}$ plastic pots for growing the plantlets at in vivo condition. When the plantlets reached 6-10 cm in length with sufficient root system then they were taken out from the vials. Medium attached to the roots were gently washed out with running tap water. The plantlets were then transplanted to pots containing the potting mixture. Immediately after transplantation, the plants along with the pots were covered with polythene bag to prevent desiccation. To reduce sudden shock, the pots were kept in growth room for 7-15 days under controlled environment.

\section{Results and Discussion}

\section{Callus induction}

Anthers from five Brassica varieties were cultured on MS medium supplemented with different concentrations of 2,4-D (1,2, and $4 \mathrm{mg} / \mathrm{L}$ with constant concentrations of BAP $(1.0 \mathrm{mg} / \mathrm{L})$ for callus induction. Callus induction performance of all the varieties in each treatment was evaluated and the results are presented in Table 1.

Table 1. Response of varieties on callus induction in Brassica species.

\begin{tabular}{l|c|c|l|l|l|l}
\hline \multicolumn{1}{c|}{ Variety } & $\begin{array}{c}\text { Days to } \\
\text { callus } \\
\text { induction }\end{array}$ & $\begin{array}{c}\text { Percent } \\
\text { callus } \\
\text { induction }\end{array}$ & $\begin{array}{c}\text { Weight of } \\
\text { callus (g) }\end{array}$ & $\begin{array}{c}\text { Colour of } \\
\text { callus }\end{array}$ & $\begin{array}{c}\text { Nature of } \\
\text { callus }\end{array}$ & $\begin{array}{c}\text { Abundance } \\
\text { of callus }\end{array}$ \\
\hline $\begin{array}{l}\text { BARI } \\
\text { Sharisha-7 }\end{array}$ & $26.75 \mathrm{a}$ & $60.42 \mathrm{a}$ & $0.128 \mathrm{a}$ & $2.813 \mathrm{a}$ & Compact & $2.854 \mathrm{a}$ \\
Tori-7 & $27.45 \mathrm{~b}$ & $39.5 \mathrm{gb}$ & $0.098 \mathrm{ab}$ & $2.708 \mathrm{ab}$ & Compact & $2.692 \mathrm{ab}$ \\
Agrani & $27.95 \mathrm{ab}$ & $31.25 \mathrm{bc}$ & $0.085 \mathrm{ab}$ & $2.688 \mathrm{ab}$ & Compact & $2.625 \mathrm{ab}$ \\
Daulat & $28.25 \mathrm{bc}$ & $22.92 \mathrm{bc}$ & $0.073 \mathrm{ab}$ & $2.615 \mathrm{~b}$ & Friable & $2.563 \mathrm{bc}$ \\
Safal & $29.04 \mathrm{c}$ & $16.67 \mathrm{c}$ & $0.04 \mathrm{gb}$ & $2.501 \mathrm{c}$ & Loose & $2.333 \mathrm{c}$ \\
\hline
\end{tabular}

Note: Mean values having common letter in the column are statistically identical and those having different letters are statistically different 
Mean square values for the varieties were found statistically significant for callus inducing characters like percent callus induction, colour of callus, abundance of callus, and non-significant for weight of callus and days to callusing (Table 2).

Table 2. Mean square values for different parameters of calli in Brassica species.

\begin{tabular}{|c|c|c|c|c|c|c|}
\hline \multirow[b]{2}{*}{$\begin{array}{c}\text { Sources of } \\
\text { variation }\end{array}$} & \multirow[b]{2}{*}{$\begin{array}{c}\text { Degrees of } \\
\text { freedom }\end{array}$} & \multicolumn{5}{|c|}{ Parameters } \\
\hline & & $\begin{array}{l}\text { Days to } \\
\text { callusing }\end{array}$ & $\begin{array}{c}\text { Percent } \\
\text { callus } \\
\text { induction }\end{array}$ & $\begin{array}{l}\text { Colour of } \\
\text { callus }\end{array}$ & $\begin{array}{c}\text { Abundance } \\
\text { of } \\
\text { callus }\end{array}$ & $\begin{array}{l}\text { Weight of } \\
\text { callus (g) }\end{array}$ \\
\hline Variety & 4 & $10.642^{\mathrm{ns}}$ & $3479.17 * *$ & $0.121^{* *}$ & $0.436 * *$ & $0.010^{\mathrm{ns}}$ \\
\hline Hormone & 2 & $407.379^{\mathrm{ns}}$ & $5541.67 * *$ & $0.800 * *$ & $0.228 *$ & $0.009^{\mathrm{ns}}$ \\
\hline $\begin{array}{l}\text { Hormone } \times \\
\text { genotype }\end{array}$ & 8 & $50.801^{\mathrm{ns}}$ & $307.29^{\mathrm{ns}}$ & $0.014^{\mathrm{ns}}$ & $0.019^{\mathrm{ns}}$ & $0.000^{\mathrm{ns}}$ \\
\hline Error & 45 & $320.189^{\mathrm{ns}}$ & $333.33^{\mathrm{ns}}$ & $0.027^{\mathrm{ns}}$ & $0.048^{\mathrm{ns}}$ & $0.004^{\mathrm{ns}}$ \\
\hline
\end{tabular}

** $1 \%$ Level of significance, $* 5 \%$ Level of significance NS = Non significant

The explant anther started callus induction from 20 to 22 days of incubation, and it took about 35 to 45 days for completion. The percentage of callus induction was highest in BARI Sharisha-7 (87.50\%) (Plate-1 and Plate-2) followed by Tori-7(62.50\%), Agrani (50.00\%) and Daulat (37.50\%). Callus induction was lowest in Safal (25.00\%) (Table 3). Mean square values of three different combinations of phytohormone were found statistically significant for the characters percent callus induction, colour of callus, abundance of callus and non-significant for weight of callus and days to callusing (Table 2). Among the treatments MS + $4 \mathrm{mg} / \mathrm{L} \mathrm{2,4-} \mathrm{D}+1.0 \mathrm{mg} / \mathrm{L}$ BAP $\left(\mathrm{T}_{3}\right)$ showed the best performance (52.50\% callus induction). Callusing was lowest in MS medium supplemented with $1 \mathrm{mg} / \mathrm{L}$ 2.4-D+l.0 mg/L BAP (20.00\%). This investigation exhibited that both the high and low concentration of 2.4-D influences callusing performance.

\section{Maintenance of calli}

Callus maintenance was essential to get regenerants from it. For this purpose, MS medium supplemented with different 2,4-D concentrations and constant concentrations of BAP were used, where MS + 4mg/L 2,4-D + $1.0 \mathrm{mg} / \mathrm{L}$ BAP was found to be the best.

\section{Organogenesis via calli}

One of the major objectives of the study was to produce regenerated plantlets from Brassica varieties using anther as explants. Different concentrations of BAP with constant concentration of NAA on MS media were used to observe the regeneration capacity of the calli. It was appeared from the study that the 
Table 3 Effects of different concentrations and combinations of phytohormone for callus induction from anther of Brassica spp.

\begin{tabular}{|c|c|c|c|c|c|}
\hline $\begin{array}{l}\text { Phytohormone } \\
\text { combinations }\end{array}$ & Varieties & $\begin{array}{c}\text { No. of } \\
\text { explants } \\
\text { inoculated }\end{array}$ & $\begin{array}{l}\text { No. of } \\
\text { explants } \\
\text { showing } \\
\text { callus } \\
\text { induction }\end{array}$ & $\begin{array}{l}\% \text { callus } \\
\text { induction }\end{array}$ & $\begin{array}{l}\text { Days req. for } \\
\text { callus } \\
\text { induction }\end{array}$ \\
\hline \multirow{5}{*}{$\begin{array}{l}\mathrm{MS}+1 \mathrm{mg} / \mathrm{L} \\
2,4-\mathrm{D}+ \\
1.0 \mathrm{mg} / \mathrm{L} \mathrm{BAP} \\
\left(\mathrm{T}_{1}\right)\end{array}$} & $\begin{array}{l}\text { BARI } \\
\text { Sharisha-7 }\end{array}$ & 16 & 05 & 31.25 & 27.625 \\
\hline & Tori-7 & 16 & 04 & 25.00 & 29.250 \\
\hline & Agrani & 16 & 03 & 18.75 & 34.125 \\
\hline & Daulat & 16 & 02 & 12.50 & 36.321 \\
\hline & Safal & 16 & 02 & 12.50 & 39.451 \\
\hline \multirow{5}{*}{$\begin{array}{l}\mathrm{MS}+2 \mathrm{mg} / \mathrm{L} 2,4 \\
-\mathrm{D}+1.0 \mathrm{mg} / \mathrm{L} \\
\operatorname{BAP}\left(\mathrm{T}_{2}\right)\end{array}$} & $\begin{array}{l}\text { BARI } \\
\text { Sharisha-7 }\end{array}$ & 16 & 10 & 62.50 & 26.250 \\
\hline & Tori-7 & 16 & 05 & 31.25 & 27.560 \\
\hline & Agrani & 16 & 04 & 25.00 & 30.125 \\
\hline & Daulat & 16 & 03 & 18.75 & 34.610 \\
\hline & Safal & 16 & 02 & 12.50 & 38.124 \\
\hline \multirow{5}{*}{$\begin{array}{l}\mathrm{MS}+4 \mathrm{mg} / \mathrm{L} \\
2,4-\mathrm{D}+1.0 \\
\mathrm{mg} / \mathrm{L} \text { BAP }\left(\mathrm{T}_{3}\right)\end{array}$} & $\begin{array}{l}\text { BARI } \\
\text { Sharisha-7 }\end{array}$ & 16 & 14 & 87.50 & 22.250 \\
\hline & Tori-7 & 16 & 10 & 62.50 & 25.450 \\
\hline & Agrani & 16 & 08 & 50.00 & 29.850 \\
\hline & Daulat & 16 & 06 & 37.50 & 33.253 \\
\hline & Safal & 16 & 04 & 25.00 & 36.624 \\
\hline
\end{tabular}

responses of shoot differentiation of different genotypes in different treatments were different. Mean square values due to genotypes were significant for all these characters indicating the presence of adequate variability among the genotypes for these characters. Among the genotypes, the regeneration performances were found better in BARI Sharisha-7 (62.50\%) followed by Tori7 (56.25\%) (Plate 3) and Agrani (47.92\%) (Table 4). 
Table 4. Response of varieties on shoot regeneration in Brassica species.

\begin{tabular}{l|l|l|l|l}
\hline \multicolumn{1}{c|}{ Varieties } & $\begin{array}{c}\text { Number of callus } \\
\text { inoculated }\end{array}$ & $\begin{array}{c}\text { Number of shoots/ } \\
\text { initiation }\end{array}$ & $\begin{array}{c}\text { Days to shoot } \\
\text { initiation }\end{array}$ & $\begin{array}{c}\text { Percent shoot } \\
\text { initiation }\end{array}$ \\
\hline BARI Sharisha-7 & 16 & $2.500 \mathrm{a}$ & $21.75 \mathrm{c}$ & $62.50 \mathrm{a}$ \\
Tori-7 & 16 & $2.250 \mathrm{th}$ & $24.39 \mathrm{bc}$ & $56.25 \mathrm{~b}$ \\
Agrani & 16 & $1.917 \mathrm{~b}$ & $26.45 \mathrm{ab}$ & $47.92 \mathrm{ab}$ \\
Daulat & 16 & $1.667 \mathrm{bc}$ & $29.06 \mathrm{~b}$ & $41.67 \mathrm{bc}$ \\
Safal & 16 & $0.917 \mathrm{c}$ & $31.65 \mathrm{a}$ & $22.92 \mathrm{c}$ \\
\hline
\end{tabular}

Note: Mean values having common letter in the column are statistically identical and those having different letters are statistically different.

Mean square values due to phytohormone combinations for number of shoots/callus and percent shoot initiation were significant, and days to shoot initiation were non-significant indicating the presence of sufficient variability among the treatments used for this study. The MS medium supplemented with $4.0 \mathrm{mg} / \mathrm{L} \mathrm{BAP}+1.0 \mathrm{mg} / \mathrm{L}$ NAA showed the highest percentage of shoot regeneration (56.25\%) (Table 5).

Table 5. Effects of media with hormone supplements on shoot regeneration in Brassica species.

\begin{tabular}{c|l|l}
\hline \multicolumn{1}{c|}{$\begin{array}{c}\text { Media with different hormone } \\
\text { supplements }\end{array}$} & \multicolumn{1}{c|}{$\begin{array}{c}\text { Days to shoot } \\
\text { initiation }\end{array}$} & $\begin{array}{c}\text { Percent shoot } \\
\text { initiation }\end{array}$ \\
\hline $\mathrm{MS}+2.0 \mathrm{mg} / \mathrm{L} \mathrm{BAP}+1.0 \mathrm{mg} / \mathrm{L} \mathrm{IAA}$ & $25.07 \mathrm{a}$ & $56.25 \mathrm{a}$ \\
$\mathrm{MS}+3.0 \mathrm{mg} / \mathrm{L} \mathrm{BAP}+1.0 \mathrm{mg} / \mathrm{L}$ IAA & $25.26 \mathrm{~b}$ & $47.50 \mathrm{~b}$ \\
$\mathrm{MS}+4.0 \mathrm{mg} / \mathrm{L} \mathrm{BAP}+1.0 \mathrm{mg} / \mathrm{L} \mathrm{IAA}$ & $24.38 \mathrm{ab}$ & $35.00 \mathrm{c}$ \\
\hline
\end{tabular}

Note: Mean values having common letter in the column are statistically identical and those having different letters are statistically different.

The results related to interaction of hormone and variety indicated that for shoot regeneration all the parameters were statistically non-significant and showed variation among the interactions (Table 6). 
Table 6. Effects of variety $\mathrm{X}$ media on shoot regeneration in Brassica species.

\begin{tabular}{|c|c|c|c|}
\hline $\begin{array}{l}\text { Media with different hormone } \\
\text { supplements }\end{array}$ & Varieties & $\begin{array}{c}\text { Days to shoot } \\
\text { initiation }\end{array}$ & \begin{tabular}{|c|}
$\begin{array}{c}\text { Percent shoot } \\
\text { initiation }\end{array}$ \\
\end{tabular} \\
\hline \multirow[t]{5}{*}{$\mathrm{MS}+2.0 \mathrm{mg} / \mathrm{L} \mathrm{BAP}+1.0 \mathrm{mg} / \mathrm{L} \mathrm{IAA}$} & BARI Sharisha-7 & $27.92 a-c$ & $75.00 \mathrm{a}$ \\
\hline & Tori-7 & $28.50 \mathrm{ab}$ & $62.50 \mathrm{a}-\mathrm{c}$ \\
\hline & Agrani & 29.46ab & $50.00 \mathrm{a}-\mathrm{d}$ \\
\hline & Daulat & 29.63a & $68.75 \mathrm{ab}$ \\
\hline & Safal & 29.88a & $56.25 a-d$ \\
\hline \multirow[t]{5}{*}{$\mathrm{MS}+3.0 \mathrm{mg} / \mathrm{L} \mathrm{BAP}+1.0 \mathrm{mg} / \mathrm{L} 1 \mathrm{AA}$} & BARI Sharjsha-7 & 23.00de & 43.75a-e \\
\hline & Tori-7 & 23.75de & $56.25 a-d$ \\
\hline & Agrani & $24.08 b-d$ & $50.00 \mathrm{a}-\mathrm{d}$ \\
\hline & Daulat & $25.50 \mathrm{a}-\mathrm{c}$ & 37.50b-e \\
\hline & Safal & $27.75 c$ & $50.00 \mathrm{a}-\mathrm{d}$ \\
\hline \multirow[t]{5}{*}{$\mathrm{MS}+4.0 \mathrm{mg} / \mathrm{L} \mathrm{BAP}+1.0 \mathrm{mg} / \mathrm{L} \mathrm{IAA}$} & BARI Sharisha-7 & $21.25 \mathrm{e}$ & 43.75a-e \\
\hline & Tori-7 & 22.00d & $31.25 c-e$ \\
\hline & Agrani & 22. 17de & $31.25 c-e$ \\
\hline & Daulat & 22.38b-e & 25.00de \\
\hline & Sfal & 22.50b-e & $12.50 \mathrm{e}$ \\
\hline
\end{tabular}

Table 7. Effects of different combinations of phytohoromone in half strength MS medium on root initiation of Brassica spp.

\begin{tabular}{|c|c|c|c|c|}
\hline \multirow[b]{2}{*}{ Phytohormone combinations } & \multirow[b]{2}{*}{ Varieties } & \multicolumn{3}{|c|}{ Parameters } \\
\hline & & $\begin{array}{l}\text { No. of shoot } \\
\text { incubated }\end{array}$ & $\begin{array}{c}\text { No. of shoot } \\
\text { showing root } \\
\text { initiation }\end{array}$ & $\begin{array}{l}\% \text { root } \\
\text { initiation }\end{array}$ \\
\hline \multirow[t]{5}{*}{$\begin{array}{l}1 / 2 \mathrm{MS}+0.5 \mathrm{mg} / \mathrm{L} \mathrm{NAA} \\
+1.0 \mathrm{mg} / \mathrm{L} \mathrm{IBA}\end{array}$} & $\begin{array}{l}\text { BARI } \\
\text { Sharisha-7 }\end{array}$ & 16 & 12 & 75.00 \\
\hline & Tori-7 & 16 & 12 & 75.00 \\
\hline & Agrani & 16 & 11 & 68.75 \\
\hline & Daulat & 16 & 10 & 62.50 \\
\hline & Safal & 16 & 9 & 56.25 \\
\hline \multirow[t]{5}{*}{$\begin{array}{l}1 / 2 \mathrm{MS}+0.5 \mathrm{mg} / \mathrm{L} \mathrm{NAA} \\
+2.0 \mathrm{mg} / \mathrm{L} \text { IBA }\end{array}$} & $\begin{array}{l}\text { BARI } \\
\text { Sharisha-7 }\end{array}$ & 16 & 11 & 68.75 \\
\hline & Tori4 & 16 & 10 & 62.50 \\
\hline & Ani & 16 & 9 & 56.25 \\
\hline & Daulat & 16 & 9 & 56.25 \\
\hline & Safal & 16 & 8 & 50.00 \\
\hline \multirow[t]{5}{*}{$\begin{array}{l}1 / 2 \mathrm{MS}+0.5 \mathrm{mg} / \mathrm{L} \mathrm{NAA} \\
+3.0 \mathrm{mg} / \mathrm{L} \mathrm{IBA}\end{array}$} & $\begin{array}{l}\text { BARI } \\
\text { Sharisha-7 }\end{array}$ & 16 & 10 & 62.50 \\
\hline & Tori-7 & 16 & 9 & 56.25 \\
\hline & Agrani & 16 & 8 & 50.00 \\
\hline & Daulat & 16 & 7 & 43.75 \\
\hline & Safal & 16 & 6 & 37.50 \\
\hline
\end{tabular}




\section{Root initiation}

Half strength MS medium with supplementation of 1.0, 2.0 and $3.0 \mathrm{mg} / \mathrm{L}$ IBA with $0.5 \mathrm{mg} / \mathrm{L}$ NAA in each treatment were used to observe rooting response of regenerated shoots of Brassica species. The highest percentage of root induction (75\%) was observed in BARI Sharisha-7 (Plate 4) and lowest (37.50\%) in Safal. Among the three treatments, half MS medium supplemented with $1.0 \mathrm{mg} / \mathrm{L}$ IBA $+0.5 \mathrm{mg} / \mathrm{L}$ NAA was found to be the best $(75.00 \%)$ for root initiation (Table 7 ).

\section{Establishment of plantiets}

After sufficient development of root system, the small plantlets were taken out from the culture vessels without damaging roots. Excess agar around the roots was washed off by running tap water to prevent microbial infection and transplanted in small plastic pots having soil: sand: cowdung (1:2:1). The pots were then transferred into the growth chamber for proper hardening of the plantlets and then these were planted in earthen pots (Plate 5 and 6) having soil: sand: cowdung (1:2:1). The survival rate of plantlet in plastic pot as well as in soil was the highest in the genotype BARI Sharisha-7 $(66.67 \%$ and $62.50 \%$, respectively) followed by Tori-7 (54.54\% and 50.00\%, respectively). The survival rate of plantlet in pot as well as in the field was the lowest in the genotypes Daulat and Safal (Table 8).

Table 8. Survival rate of regenerants from anther of five varieties of Brassica spp. after transfer in soil.

\begin{tabular}{|c|c|c|c|c|}
\hline & \multirow[b]{2}{*}{ Varieties } & \multicolumn{3}{|c|}{ Regenerants } \\
\hline & & $\begin{array}{c}\text { No. of } \\
\text { plantlets } \\
\text { transplanted }\end{array}$ & $\begin{array}{c}\text { No. of plants } \\
\text { survived }\end{array}$ & \begin{tabular}{|c} 
Survival rate \\
(\%)
\end{tabular} \\
\hline \multirow[t]{5}{*}{ In plastic pot (with soil) } & $\begin{array}{l}\text { BARI } \\
\text { Sharisha-7 }\end{array}$ & 12 & 8 & 66.67 \\
\hline & Tori-7 & 11 & 6 & 54.54 \\
\hline & Agrani & 9 & 4 & 44.44 \\
\hline & Daulat & 8 & 2 & 25.00 \\
\hline & Safal & 5 & 1 & 20.00 \\
\hline \multirow[t]{5}{*}{ In earthen pot (with soil) } & $\begin{array}{l}\text { BARI } \\
\text { Sharisha-7 }\end{array}$ & 8 & 5 & 62.50 \\
\hline & Tori-7 & 6 & 3 & 50.00 \\
\hline & Agrani & 4 & 2 & 50.00 \\
\hline & Daulat & 2 & 0 & 0.00 \\
\hline & Safal & 1 & 0 & 0.00 \\
\hline
\end{tabular}




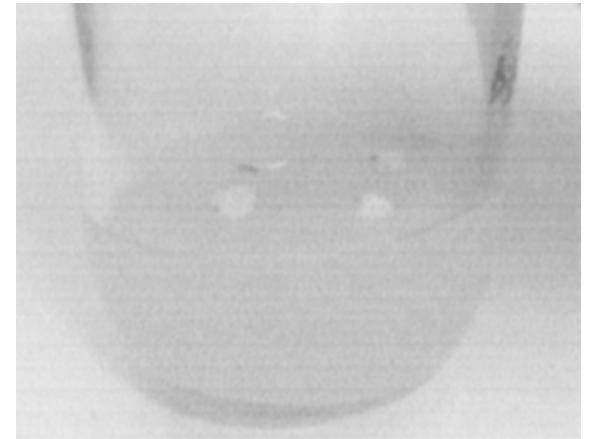

Plate 1. Callus initiation form anther of the genotype BARI Sharisha-7 in $\mathrm{MS}+4 \mathrm{mgL}^{-}$ ${ }^{1} 2,4-\mathrm{D}+1.0 \mathrm{mgL}^{-1} \mathrm{BAP}$ after 20 days of inoculation.

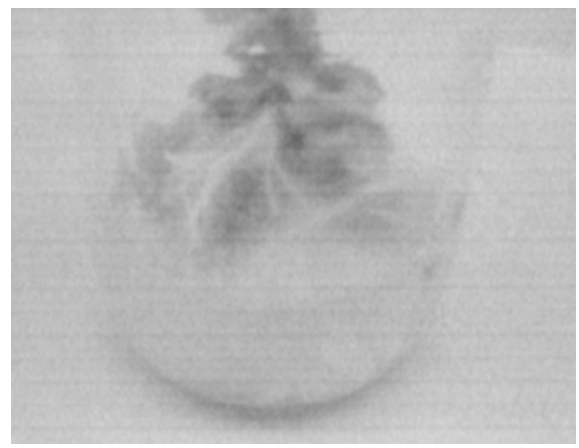

Plate 3. Shoot regeneration form derived calli of the genotype Tori-7 in MS $+4 \mathrm{mgL}^{-}$ ${ }^{1} \mathrm{BAP}+1.0 \mathrm{mgL}^{-1} \mathrm{NAA}$

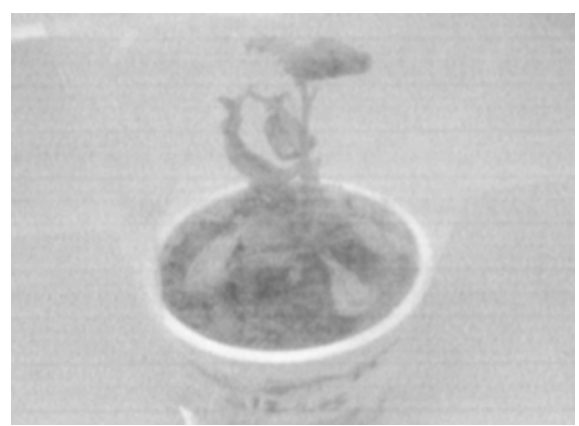

Plate 5. Regenerated plant of BARI Sharisha-7 from anther in plastic covered with polythen bag kept in net house for hardening

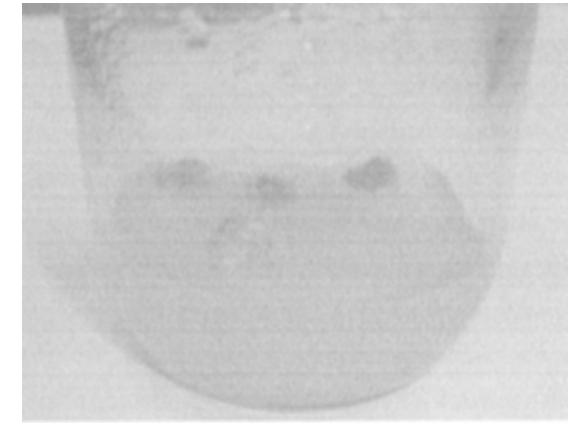

Plate 1. Callus initiation form anther of the genotype BARI Sharisha-7 in $\mathrm{MS}+4 \mathrm{mgL}$ ${ }^{1} 2,4-\mathrm{D}+1.0 \mathrm{mgL}^{-1} \mathrm{BAP}$ after 30 days of inoculation.

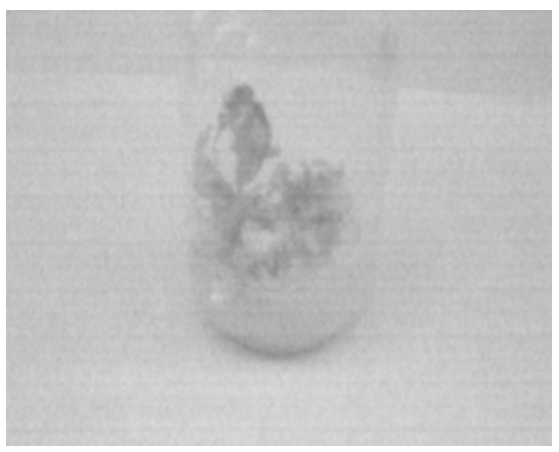

Plate 4. Initiation roots from regenerated shoot of the genotype BARI Sharisha-7 anther in half $\mathrm{MS}+1.0 \mathrm{mgL}^{-1} \mathrm{IBA}+$ $0.5 \mathrm{mgL}^{-1} \mathrm{NAA}$

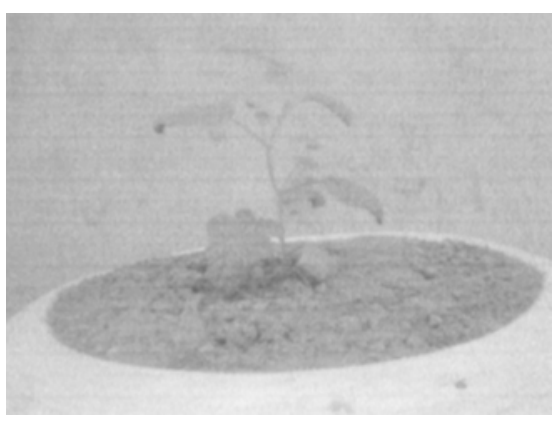

Plate 6. Regenerated plant from anther of the genotype BARI Sharisha-7 in earthen pot 
In this experiment, in vitro regeneration potentiality of five Brassica varieties has been observed and an efficient as well as reproducible protocol for regeneration of the genotypes has been developed using anther as explants. Since genetic engineering of crop plants relies on the development of efficient methods for the regeneration of viable haploid plantlets (using anther), this protocol can be followed for genetic manipulation for improvement of Brassica species. Considering the findings, further investigation is required for the callus induction and subsequent haploid production of the five varieties of Brassica by changing the type of media, hormonal composition and by trying additional growth regulators rather than those were used.

\section{References}

Downey, R. K. and G. Robbelen. 1989. Brassica species: Oil crops of the world, their breeding and utilization. Mc Graw Hill Publishing Co., New York. pp. 339-374.

FAO. 2003. Production Year Book for 2001. FAO. UN. Italy. Rome. p. 118.

Huang, N., S. McCouch, T. Mew, A. Parco and E. Guiderdoni. 1994. Development of an RFLP map from doubled haploid population rice. Rice Genet. Newl. 11: 134-137

Jain, S. M., S. K. Sopory and R. E. Vielleux. 1996. in viro haploid production in higher plants. Kluwer Academic Publishers, Netherlands. Vol. 1, 145-176.

Kasha, K. J., A. Ziauddin and U. H. Cho. 1990. Haploid in cereal improvement: anther and microspore culture. In: Gene manipulation in plant improvement II (Gustafson, J. P. ed.) 19th Stadler Genetics Symposium, New York: Plenum 213-235.

Keller, W. A. and K. C. Armstrong. 1977. Embryogenesis and plant regeneration in Brassica napus anther cultures. Can. J. Bot. 55: 1383-1388

Murashige, T. and F. Skoog. 1962. A revised medium for rapid growth and bioassays with tobacco tissue cultures. Physiol. Plant. 15: 473-497.

Piazza, G. J. and T. A. Foslia. 2001. Rapeseed oil for oleochemical usage. European J. of Lipid Sci. and Tech. 103: 450-454.

Razdan, M. K. 1993. An Introduction to Plant Tissue Culture, Oxford \& IBH Publishing Co. Pvt. Ltd., New Delhi. pp. 118-122.

Walker, K. C. and E. J. Booth. 2001. Agricultural aspects of rape and other Brassica products. European Journal of Lipid Science and Technology 103: 441-446.

Wenzel, G., F. Hoffman and E. Thomas. 1977a. Anther culture as a breeding tool in rape. Z. Pfl.Zucht. 78: 149-155.

Zivy, M., P.1. Devaux, J. Blaisonneaux, R. Jean and H. Threilment. 1992. Segregation distortion and linkage studies microspore-derived doubled haploid lines of Hordeum vulgare L. Theor. AppI. Genet. 83: 919-924. 